УДК 619:616.995.7:636.52/58:631.11(477.53)

(C) 2013

Хижня Л. Ю., аспірант *

Полтавська державна аграрна академія

\title{
ПОШИРЕННЯ МАЛОФАГОЗІВ КУРЕЙ У ГОСПОДАРСТВАХ ПОЛТАВСЬКОЇ ОБЛАСТІ
}

\section{Рецензент - кандидат ветеринарних наук Н. С. Щербакова}

\begin{abstract}
Дослідженнями встановлено широке розповсюдження малофагозів курей у господарствах Полтавської області (Зіньківський, Пирятинський, Гадяцький та Карлівський райони). Екстенсивність інвазії в середньому становила 53,3\% з інтенсивністю інвазії II=3,8 $\pm 0,01$ екз. $/ 10 x 10$ см поверхні тіла птиці. На території даного регіону у курей виділено чотири види малофаг: три види з родини Мепоропidae

(Menopon gallinae, Menacanthus stramineus,

Menacanthus cornutus) та один вид із родини Goniodidae (Goniocotes hologaster).
\end{abstract}

Ключові слова: кури, малофагоз, екстенсивність, інтенсивність інвазії, види малофаг.

Актуальність проблеми. В умовах концентрації великої кількості поголів'я свійської птиці на обмеженій території, тобто високої щільності посадки, достатньо високій технологічній температурі та вологості тривалий цикл утримання яйценосної птиці в одному пташнику створюють ідеальні умови для інтенсивного розвитку популяцій ектопаразитів [1]. Малофагози (хвороби курей, які викликаються пухопероїдами) - це проблема, що десятиріччями $є$ спільною й актуальною для всіх технологічних форм ведення птахівничої галузі [2]. Пухопероїди, в разі живлення змертвілим епідермісом, кров'ю, лімфою та жировими виділеннями, пошкоджують шкірні покриви птахів, часто поїдають пухову частину пір'я, а іноді й все віяло. Паразитуючи на поверхні тіла птиці, малофаги викликають переподразнення нервових рецепторів - з'являється свербіж, випадає пір'я, що є стресовими факторами, негативно впливаючи на загальний стан курей.

Аналіз останніх досліджень і публікацій, у яких започатковано розв'язання проблеми. Проведений нами аналіз літературних джерел вказує на те, що пухопероїди розповсюджені на всіх континентах світу. Вітчизняні вчені доводять значне поширення малофаг серед курей птахогосподарств України. У багатьох пташниках ураженість малофагами птахівничого поголів'я досягає 100 \% [6]. За даними Л. В. Нагорної, в яйценос- них птахівничих господарствах промислового типу та спеціалізованих бройлерних господарствах збудники ектопаразитозів відсутні. Про значне поширення малофагозів домашніх птахів повідомляють не тільки вітчизняні, але й зарубіжні дослідники. Високу ураженість птиці пухопероїдами діагностують лікарі Сполучених Штатів Америки, Південної Азії та Африки [2]. Екстенсивність інвазії у птахогосподарствах країн Свропи коливається від 53 до $92 \%$ [2]. Поширення та видовий склад пухопероїдів у господарствах Полтавської області вивчені недостатньо, тому вирішення цього питання в даному регіоні $\epsilon$ надзвичайно актуальним, чим і обумовлюється вибір теми даного дослідження.

Мета і завдання досліджень. Мета нашої роботи - вивчення розповсюдження малофагозів курей у господарствах Полтавської області.

До завдань входить вивчення видового складу паразитів і визначення екстенсивності та інтенсивності інвазії (ЕI та II).

Матеріали і методи досліджень. Дослідження проводили впродовж 2011-2012 рр. на базі птахогосподарств Зіньківського, Пирятинського, Гадяцького та Карлівського районів Полтавської області 3 підлоговою технологією утримання птиці різних вікових груп. Обстежували курей яєчних порід кросів Хай-Лайн, Tetra-SL, Lohman White, Lohman Braun та Браун-Нік. Паразитологічні дослідження, зокрема мікроскопію пухопероїдів, виконували на базі лабораторії кафедри паразитології та ветеринарно-санітарної експертизи Полтавської державної аграрної академії. Загальна кількість обстеженого поголів'я становить 645 голів. Із метою вивчення поширення малофагозів проводили клінічний огляд курей та збір комах, передусім звертаючи увагу на загальний стан пір'євого покриву. Досліджували птицю вибірково, по 10 особин у дрібних господарствах, а в тих пташниках, де поголів'я курей налічувалося більше тисячі, - обстежували по 10 голів із кожної тисячі в п’яти точках приміщення.

* Науковий керівник - доктор ветеринарних наук В. О. Свстаф'єва 
СТОРІНКА МОЛОДОГО ВЧЕНОГО

Поширення малофагозів курей у господарствах Полтавськой області

\begin{tabular}{|c|c|c|c|}
\hline Райони & $\begin{array}{c}\text { Кількість поголів'я } \\
\text { (досліджено гол.) }\end{array}$ & EI, \% & $\begin{array}{c}\text { II, екз./10 см } \\
\text { (min-max) }\end{array}$ \\
\hline Зіньківський & $3171(285)$ & 64,29 & $4,5-6,0$ \\
\hline Карлівський & $1918(105)$ & 18,63 & $1,5-2,0$ \\
\hline Пирятинський & $1855(120)$ & 58,3 & $3,43-4,3$ \\
\hline Гадяцький & $1499(135)$ & 71,85 & $4,29-4,6$ \\
\hline Усього: & $8443(645)$ & 53,3 & $3,43-4,22$ \\
\hline
\end{tabular}

Птахів оглядали, перебираючи пір'я рукою. Зауважимо, що пір'я здорової птиці було гладке й блискуче, пір'їни щільно прилягали одна до одної. Ламкість, пошкодження пір'я й стержнів свідчило про зараження птиці ектопаразитами. На спині, голові, навколо клоаки та під крилами виявляли малофаг на різних стадіях розвитку.

Після огляду птиці та підрахунку виявлених комах на поверхні тіла курей визначали ступінь іiі ураженості пухопероїдами (екстенсивність та інтенсивність інвазіі). Відібраних із шкірних покривів птиці малофаг фіксували в 70-градусному етиловому спирті, 3 подальшим приготуванням препаратів і визначенням видового складу паразитів.

Результати дослідження. За результатами проведених паразитологічних обстежень курей птахогосподарств Полтавської області виявлено значне поширення малофагозної інвазії в Зіньківському, Пирятинському, Гадяцькому та Карлівському районах (див. табл.). У цілому в обстежених господарствах встановлена висока ураженість курей збудниками малофагозів (EI=53,3 \%, II=3,8 $\pm 0,01$ екз. $/ 10 \mathrm{~cm}^{2}$ поверхні тіла птиці).

Екстенсивність ураження курей малофагозами у господарствах Полтавської області коливалася від $18,63 \%$ до $71,85 \%$. Максимальне ураження спостерігали у птиці Гадяцького району $(71,85 \%)$, середня інтенсивність інвазії при цьому становила - 2,96 $\pm 0,01$ екз./10 см². Ураженість птиці Зіньківського та Пирятинського районів становила $64,29 \%$ і 58,3\% за середньої інтенсивності інвазії

\section{БІБЛІОГРАФІЯ}

1. Арестов О. А. Ектопаразити курей / О. А. Арестов, М. В. Шустрова, М. В. Розовенко // Ветеринарія. 1998. - № 10. - C. 33-35.

2. Аюпов X. B. Інфекційні і паразитарні хвороби сільськогосподарських тварин і птиці / Х. В. Аюпов, П. Т. Твердохлєбов. - М. : Агропромиздат, 1980. $520 \mathrm{c}$.

3. Богач $M$. В. Інвазійні хвороби домашньої птиці: навчальний посібник / М. В. Богач, А. В. Березовський, І. Л. Тараненко - К. : Ветінформ, 2007. - $275 \mathrm{c}$.

4. Вержиховський O. Епізоотичний стан птахів-
$5,25 \pm 0,02$ i $3,87 \pm 0,01 \quad$ екз./10 см $^{2}$ відповідно. У пташниках Карлівського району екстенсивність інвазії була невисокою (18,63 \%). Середні показ-

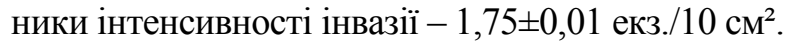

На території Полтавської області у курей виділено чотири види малофаг: три види 3 родини Menoponidae (Menopon gallinae, Menacanthus stramineus, Menacanthus cornutus) та один вид із родини Goniodidae (Goniocotes hologaster).

Найчастіше виявляли види Menopon gallinae, Menacanthus stramineus та Menacanthus cornutus, яких знаходили на контурних перах другого і третього порядків, а також на покривних перах тулуба. На внутрішній поверхні контурного пір'я другого порядку медіальної поверхні крил виявляли білі напівпрозорі подовжені яйця комах.

Значно рідше знаходили вид Goniocotes hologaster. Ектопаразити даного виду локалізувалися на шкірі тулуба, біля клоаки, на вентральній поверхні тіла та дрібних пухових перах.

\section{Висновки:}

1. Встановлено значну ураженість курей різних вікових груп збудниками малофагозів у господарствах Полтавської області. Екстенсивність інвазії, в середньому, становила 53,3\%, інтенсивність - 3,8 $\pm 0,01$ екз. $/ 10 \mathrm{~cm}^{2}$.

2. На території Полтавської області у курей виділено чотири види малофаг: три види 3 родини Menoponidae (Menopon gallinae, Menacanthus stramineus, Menacanthus cornutus) та один вид - iз родини Goniodidae (Goniocotes hologaster).

ництва в Україні / О. Вержиховський, Ю. Колос, В. Титаренко [та ін.] // Ветеринарна медицина України. - 2007. - № 6. - С. 8-10.

5. Галат В. Ф. Інвазійні хвороби, профілактика i лікування / В. Ф. Галат // Ветеринарна медицина, 1998. - № 4. - C. 42-43.

6. Нагорна Л. В. Ефективність препарату Ектосан при обробці курей за паразитування постійних ектопаразитів - представників ряду Mallophaga / Л. В. Нагорна // Міжвід. наук. темат. зб. «Птахівництво». - 2008. - Вип. 62. - С. 3-8. 